\title{
Antiestrogenic Action of Dihydrotestosterone in Mouse Breast Competition with Estradiol for Binding to the Estrogen Receptor
}

Richard W. Casey and Jean D. Wilson

Department of Internal Medicine, The University of Texas

Health Science Center at Dallas, Southwestern Medical School, Dallas, Texas 75235

bstract. Feminization in men occurs when the effective ratio of androgen to estrogen is lowered. Since sufficient estrogen is produced in normal men to induce breast enlargement in the absence of adequate amounts of circulating androgens, it has been generally assumed that androgens exert an antiestrogenic action to prevent feminization in normal men. We examined the mechanisms of this effect of androgens in the mouse breast.

Administration of estradiol via silastic implants to castrated virgin CBA/J female mice results in a doubling in dry weight and DNA content of the breast. The effect of estradiol can be inhibited by implantation of $17 \beta$ hydroxy-5 $\alpha$-androstan-3-one (dihydrotestosterone), whereas dihydrotestosterone alone had no effect on breast growth. Estradiol administration also enhances the level of progesterone receptor in mouse breast. Within $4 \mathrm{~d}$ of castration, the progesterone receptor virtually disappears and estradiol treatment causes a twofold increase above the level in intact animals. Dihydrotestosterone does not compete for binding to the progesterone receptor, but it does inhibit estrogen-mediated increases of progesterone receptor content of breast tissue cytosol from both control mice and mice with $\mathrm{X}$ linked testicular feminization $(\mathrm{tfm}) / \mathrm{Y}$. Since $t \mathrm{fm} / \mathrm{Y}$ mice lack a functional androgen receptor, we conclude that this antiestrogenic action of androgen is not mediated by the androgen receptor.

Dihydrotestosterone competes with estradiol for binding to the cytosolic estrogen receptor of mouse

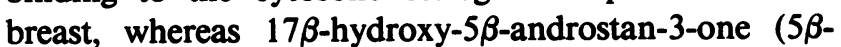
dihydrotestosterone) neither competes for binding nor

Received for publication 30 April 1984.

J. Clin. Invest.

(C) The American Society for Clinical Investigation, Inc.

0021-9738/84/12/2272/07 \$1.00

Volume 74, December 1984, 2272-2278 inhibits estradiol-mediated induction of the progesterone receptor. Dihydrotestosterone also promotes the translocation of estrogen receptor from cytoplasm to nucleus; the ratio of cytoplasmic-to-nuclear receptor changes from $3: 1$ in the castrate to $1: 2$ in dihydrotestosteronetreated mice.

Thus, the antiestrogenic effect of androgen in mouse breast may be the result of effects of dihydrotestosterone on the estrogen receptor. If so, dihydrotestosterone performs one of its major actions independent of the androgen receptor.

\section{Introduction}

Normal men produce $\sim 45 \mu \mathrm{g}$ of estradiol each day, a sixth of which is secreted by the testes and the remainder of which is derived from the extraglandular aromatization of circulating androgens (1). Extraglandular estradiol formation takes place by two mechanisms, one from the direct conversion of testosterone to estradiol and the other from androgens of adrenal origin by the sequence of androstenedione $\rightarrow$ estrone $\rightarrow$ estradiol. The function of estradiol in normal men is unknown, but feminization, commonly manifested by gynecomastia, ensues under conditions of relative or absolute estrogen excess (2).

Relative estrogen excess occurs when the synthesis or action of androgen is impaired but estrogen production is maintained at or near normal (as occurs in testicular regression or in testicular failure when testicular androgen production ceases but the formation of estrogens from adrenal androgens is unimpaired $[3,4])$. Thus, in the absence of the opposing effects of androgen, sufficient estrogen is produced by normal men to result in profound breast enlargement. Alternatively, estrogen production can increase above the normal range either because of enhanced testicular secretion of estradiol (as in certain testicular tumors) $(5,6)$ or because of increased formation of estrogen in extraglandular sites (as in cirrhosis of the liver) $(2,7)$. Since the development of feminizing signs is similar in such fundamentally different disorders, Lewin (8) originally proposed that the determinant of feminization in men is not so much the absolute level of estrogen but rather 
the ratio of androgen to estrogen, a concept that has received support from detailed studies of androgen and estrogen metabolism in men with feminization in diverse clinical states $(2,9)$.

The mechanism by which androgen inhibits estrogen action is unknown. Evidence has been developed in the MCF7 cell line that $17 \beta$-hydroxy-5 $\alpha$-androstan-3-one (dihydrotestosterone) ${ }^{1}$ functions as an antiestrogen by binding to the estrogen receptor itself and like certain other antiestrogens, that dihydrotestosterone can act as a weak estrogen in high concentration (10). Alternatively, the antiestrogenic actions of androgen on the embryonic mouse breast (11) and on the rodent uterus (12) appear to be mediated via the androgen receptor, e.g., androgen induces some action at the genomic level that blunts the estrogenic response. To provide insight into the process by which androgens antagonize estrogen action on the breast in mature animals, we investigated the interaction of these two hormones on the mouse breast.

\section{Methods}

Materials. $\left[2,4,6,7-{ }^{3} \mathrm{H}\right]$ Estradiol $(112 \mathrm{Ci} / \mathrm{mmol})$ and [17 $\alpha$-methyl${ }^{3} \mathrm{H}$ ]promegestone (17,21-dimethyl-19-nor-pregna-4,9-diene-3,20-dione) ( $77 \mathrm{Ci} / \mathrm{mmol}$ ) were obtained from New England Nuclear Corp., Boston, MA. Acetyl bovine serum albumin was prepared by acetylation with $\left[{ }^{14} \mathrm{C}\right]$ acetic anhydride (New England Nuclear Corp.) (13). Unlabeled steroids were from Steraloids, Inc., Wilton, NH. Radiolabeled steroids were checked for purity by thin-layer chromatography.

Animals. Virgin female CBA/J mice were obtained from Jackson Laboratories and were studied at $12 \mathrm{wk}$ of age or older. Mice carrying the X-linked testicular feminization gene $(t f m)$ were bred in our laboratory. The mice carrying the $t f m$ gene have been inbred with C57/BL6 mice carrying a coat color marker tabby $(t a)$ that is closely linked to the $t f m$ gene. In experiments utilizing these mice, $+t f m / Y$ males were compared with $t a+/ t a+$ littermate females. In other experiments, $t a+1+t f m$ females were outbred to $++/ \mathrm{Y}$ CBA/J males, and the $t \mathrm{fm} / \mathrm{Y}$ offspring were compared with female littermates that were a mixture of $t a+/++$ and $+t f m /++$ genotypes.

Mice were castrated through a posterior incision under ether anesthesia, subjected to a variety of hormone regimens, and killed at appropriate intervals by cervical dislocation. The posterior inguinal mammary glands were excised and, if receptor studies were to be performed, placed in cold $\left(0-4^{\circ} \mathrm{C}\right)$ buffer. For studies of breast weight and DNA content, each breast was defatted by a 48-h wash in $10 \mathrm{ml}$ of 2:1 chloroform:methanol solution followed by a 24-h wash in 10 $\mathrm{ml}$ of ethyl ether (14). The tissue was then dried in an oven at $50^{\circ} \mathrm{C}$ for $2 \mathrm{~d}$ and weighed. DNA content was determined in the defatted breast tissue by the method of Burton (15).

Hormone treatment. Hormone implants were prepared by packing silastic tubing (Dow Corning medical grade silastic tubing no. 602285, Dow Chemical Co., Indianapolis, IN) with crystalline steroids,

1. Abbreviations used in this paper: $3 \alpha$-androstanediol, $5 \alpha$-androstane$3 \alpha, 17 \beta$-diol; $3 \beta$-androstanediol, $5 \alpha$-androstane- $3 \beta, 17 \beta$-diol; dihydrotestosterone, $17 \beta$-hydroxy- $5 \alpha$-androstan-3-one; $5 \beta$-dihydrotestosterone, $17 \beta$-hydroxy-5 $\beta$-androstan-3-one; promegestone, 17,21-dimethyl-19-norpregna-4,9-diene-3,20-dione; $t a$, tabby gene; $t f m$, testicular feminization gene. and the ends were sealed with Dow Corning 734 TRV self-leveling adhesive sealant. Capsule sizes for the estradiol implants were 0.1, 0.3, $0.5,0.7$, and $1.0 \mathrm{~cm}$ and contained $\sim 1.5,2.5,5.0,7.5$, and $10.0 \mathrm{mg}$ of estradiol, respectively. Similar lengths were used for dihydrotestosterone administration. Steroid release rates were calculated by the method of Foote and Greene (16) and ranged between 0.3 and $3.5 \mu \mathrm{g} /$ $\mathrm{d}$ for estradiol and between 2.0 and $10 \mu \mathrm{g} / \mathrm{d}$ for dihydrotestosterone. Implants were stored dry and rinsed with $95 \%$ ethanol before insertion to remove any loosely adherent steroid. Implants were placed subcutaneously and left in situ until the time of death.

Studies of breast weight and DNA composition. Groups of 10 castrated mice were implanted with varying amounts of estradiol. After $2 \mathrm{wk}$, the animals were killed, the breast tissue was removed and weighed, and the DNA content of the defatted breasts was measured. The smallest estradiol implant producing maximal breast growth was selected, and the experiment was repeated with all mice receiving this estradiol implant and varying sizes of dihydrotestosterone implants. After $2 \mathrm{wk}$, the animals were killed; breast weights and the DNA content were measured as before.

Induction of the progesterone receptor. Groups of 10 castrated animals were implanted with silastic capsules containing varying amounts of estradiol (no implant, $0.1,0.3,0.5,0.7$, and $1.0 \mathrm{~cm}$ ). After $4 \mathrm{~d}$, the animals were killed, and the binding of $\left[{ }^{3} \mathrm{H}\right]$ promegestone by the mouse mammary tissue cytosol was measured in each group. The capsule size producing the greatest increase in cytosolic progesterone receptor was chosen, and the experiment was repeated with all animals receiving a similar estradiol capsule and increasing length of dihydrotestosterone implants.

Preparation of mammary gland cytosol and nuclear extract. Excised breast tissue was placed in cold $\left(0-4^{\circ} \mathrm{C}\right)$ TEGSH buffer $(0.01 \mathrm{M}$ Tris, $1.5 \mathrm{mM}$ EDTA, $0.1 \%$ monothioglycerol, $10 \%$ glycerol, $10 \mathrm{mM}$ sodium molybdate, $\mathrm{pH}$ 7.4). In some samples the TEGSH buffer contained $0.4 \mathrm{M} \mathrm{KCl}$. The tissue was washed three times, suspended in appropriate buffer $(0.5 \mathrm{ml} / \mathrm{mammary}$ gland), and homogenized using three 10 -s bursts with a Brinkmann polytron (Brinkmann Instruments, Westbury, NY) at $70 \%$ maximum and with 60 -s cooling between each burst. The homogenate was then centrifuged at $100,000 \mathrm{~g}$ for $60 \mathrm{~min}$ and divided into particulate and soluble fractions. The thick lipid layer that floats to the top was pierced with a Pasteur pipette for removal of the cytosolic fraction, which was used as a receptor source.

The particulate pellet was washed three times with TEGSH buffer and suspended in TEGSH containing $0.4 \mathrm{M} \mathrm{KCl}$ and homogenized. After $1 \mathrm{~h}$ at $0-4^{\circ} \mathrm{C}$, the nuclear material was pelleted as previously described and the supernate was utilized as a source for nuclear receptors. Protein content in the cytosol and nuclear extracts was measured by the method of Lowry et al. (17).

Sucrose gradient analysis. Samples for gradient centrifugation were prepared by incubation of $0.3 \mathrm{ml}$ of nuclear or cytosolic fractions with appropriate concentrations of $\left[{ }^{3} \mathrm{H}\right]$ estradiol or $\left[{ }^{3} \mathrm{H}\right]$ promegestone with or without 150-fold excess of nonradioactive steroids for $4 \mathrm{~h}$ at 0 $4^{\circ} \mathrm{C}$. In experiments involving dihydrotestosterone administration and estrogen receptor measurement, maximal binding occurred within $4 \mathrm{~h}$ (results not shown). Unbound steroid was removed by the addition of $75 \mu \mathrm{l}$ of dextran-coated charcoal in TEGSH buffer $(50 \mathrm{mg} / \mathrm{ml})$. The mixture was centrifuged, and $0.2 \mathrm{ml}$ of the supernate was applied to 5 - $\mathrm{ml}$ linear $5-20 \%$ sucrose gradients in TEGSH. $\left[{ }^{14} \mathrm{C}\right]$ albumin $(1,600$ $\mathrm{dpm}$ of ${ }^{14} \mathrm{C}$ ) was added to the top to serve as an internal marker in some experiments. The gradients were centrifuged for $18 \mathrm{~h}$ in a SW50.1 rotor at $50,000 \mathrm{rpm}(250,000 \mathrm{~g})$ at $0^{\circ} \mathrm{C}$ in a Beckman ultracentrifuge (Beckman Instruments, Spinco Div., Palo Alto, CA). Four-drop fractions 
were collected from the top of the tube using an ISCO gradient fractionator (Model 640, ISCO, Lincoln, NE) and assayed for radioactivity in $10 \mathrm{ml}$ Budget Solve (Research Products International Corp., Mount Prospect, IL) in a Packard 2650 liquid scintillation counter (Packard Instrument Co., Downers Grove, IL) with an ${ }^{3} \mathrm{H}$-efficiency of $\sim 30 \%$ in dual-label counting. The ${ }^{14} \mathrm{C}$-efficiency in the ${ }^{3} \mathrm{H}$-channel was $6 \%$. The disintegrations per minute of ${ }^{3} \mathrm{H}$ were calculated from stored quench curves. Sedimentation values were estimated by the method of Martin and Ames (18), and the areas under the peaks were estimated by the method of Bartlet and Smith (19). The amount of receptor binding in the peak was calculated as femtomoles per milligram protein.

Competition experiments. Cytoplasmic extracts were incubated with $5 \mathrm{nM}\left[{ }^{3} \mathrm{H}\right]$ estradiol and increasing quantities of unlabeled estradiol, dihydrotestosterone, testosterone, $5 \alpha$-androstane- $3 \beta, 17 \beta$-diol (3 $\beta$-androstanediol), or $17 \beta$-hydroxy-5 5 -androstan-3-one ( $5 \beta$-dihydrotestosterone) for $18 \mathrm{~h}$ at $0-4^{\circ} \mathrm{C}$. Parallel incubations with $1 \mu \mathrm{M}$ unlabeled estradiol were used to determine nonspecific binding. Samples were then analyzed by sucrose gradient centrifugation.

\section{Results}

Normal male mice undergo androgen-mediated regression of the breast anlage during embryogenesis, and consequently, breast development is precluded in the male mouse (20). Therefore, we either studied virgin female mice or male $t f m$ mice that do not make a functional androgen receptor and as a consequence do not undergo androgen-mediated breast regression during embryogenesis. In preliminary studies we found that the inguinal breasts are easier to dissect free of muscle tissue than are the anterior breasts, and therefore, we utilized the inguinal breasts to study the interaction of androgen and estrogen in breast growth. Groups of female mice were castrated and implanted with varying amounts of estradiol. 2 wk later the inguinal breast pads were removed, defatted and dried, and analyzed for weight and for DNA content (Fig. 1). Castration caused little change in dry weight or DNA content. Estrogen treatment of the castrated mice caused an increase in both weight and DNA content, but the maximal increase in each parameter (achieved at the $0.5-\mathrm{cm}$ dosage level) was less than twice that of the castrate control.

The implantation of dihydrotestosterone capsules together with $0.5 \mathrm{~cm}$ estradiol capsules prevented the estradiol-mediated enhancement in the dry weight and DNA content of the breast (Fig. 2). All doses of dihydrotestosterone examined inhibited the effect of estrogen, whereas dihydrotestosterone alone had no measurable effects on the breast even at doses as high as $1.0 \mathrm{~cm}$ for $2 \mathrm{wk}$ (results not shown). We concluded that dihydrotestosterone does act as an antiestrogen in the breast of the female mouse, but the findings in regard to both growth and DNA content were significant only at the $P \leq 0.05$ level. The lack of more clear-cut effects of dihydrotestosterone is almost certainly due to the fact that the mammary epithelium constitutes only a fraction of the defatted mammary pad, along with defatted adipocytes and fibroblasts (21). Therefore, we sought another index of the estrogen effect on the breast to utilize in the study of estrogen and androgen interaction.

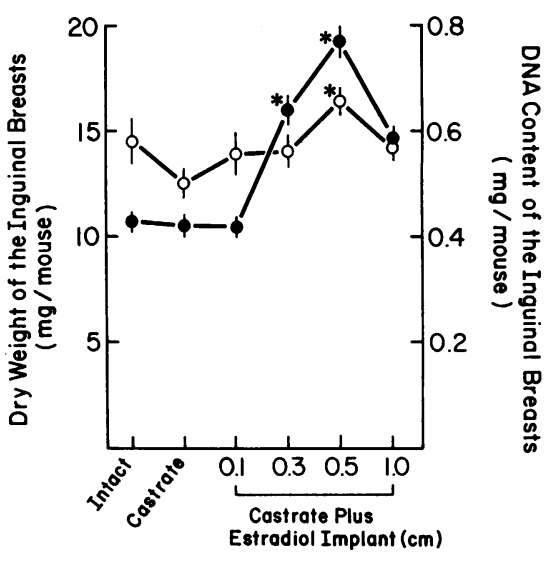

Figure 1. Effect of estradiol implants on the weight (-O-) and DNA content (- - ) of mouse breasts. 12-wk-old virgin female mice of the CBA/J strain were either kept intact or castrated and implanted with estradiol in silastic capsules as indicated. After 2 wk, the animals were killed, and the two inguinal breasts were dissected, defatted, weighed, and analyzed for DNA content. Each group was comprised of 10 animals, and the results are plotted as mean determinations $\pm S E M$. The asterisk designates a significant difference $(P<0.05)$ between treated and castrate control animals using the Student's $t$ test.

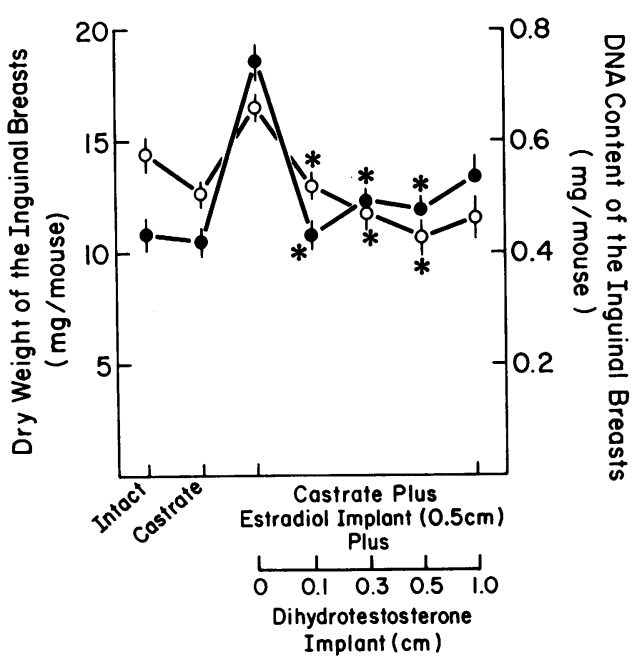

Figure 2. Effect of dihydrotestosterone on estradiol-stimulated growth of the mouse breast. 12-wk-old virgin female mice of the CBA/J strain were either kept intact or castrated. Some castrates were implanted with $0.5 \mathrm{~cm}$ estradiol in silastic tubing, and others received in addition dihydrotestosterone implants as indicated. After 2 wk, the animals were killed, and the two inguinal breasts were dissected, defatted, weighed, and analyzed for DNA content. Each group was comprised of 10 animals, and the results are plotted as mean determinations \pm SEM. The asterisk indicates significant differences $(P<0.05)$ between animals receiving estradiol alone and those receiving estradiol plus dihydrotestosterone. Symbols are the same as those in Fig. 1. 
The regulation of the content of the progesterone receptor in the breast of many species including the mouse is under the control of estrogen $(21,22)$, and therefore, we designed experiments to study the interaction of androgen and estrogen on the breast progesterone receptor. The sucrose density gradient analysis of the binding of the synthetic progestogen, $\left[{ }^{3} \mathrm{H}\right]$ promegestone, in cytosol of mouse breast is illustrated in Fig. 3. As previously described by Haslam and Shyamala (21), the progesterone receptor of mouse breast centrifuges predominately as a $4 \mathrm{~S}$ entity. This binding is prevented by nonradioactive promegestone or progesterone, but is not influenced by the addition of dihydrotestosterone to the cytosol preparation (results not shown).

The effects of varying sizes of estradiol implants on $\left[{ }^{3} \mathrm{H}\right]$ promegestone binding are illustrated in Fig. 4. The receptor level in intact CBA/J females averages $\sim 30 \mathrm{fmol} / \mathrm{mg}$ protein and decreases to $<5 \mathrm{fmol} / \mathrm{mg}$ protein at $5 \mathrm{~d}$ after castration. Estradiol implants that varied from 0.1 to $0.7 \mathrm{~cm}$ in length were inserted on the day of castration. At the 0.1 and $0.3 \mathrm{~cm}$ dosages, the progesterone receptor was maintained at precastrate levels. Larger doses $(0.5,0.7$, and $1.0 \mathrm{~cm})$ caused a twofold increase in promegestone binding above the level in intact animals and approximately a 12-fold increase above that in the castrated controls. Thus, the differences between castrate and treated animals were of a sufficient magnitude to allow a detailed study of the interaction of dihydrotestosterone and estradiol.

Dihydrotestosterone prevents the estradiol-mediated increase in the amount of the progesterone receptor (Fig. 5). 0.1

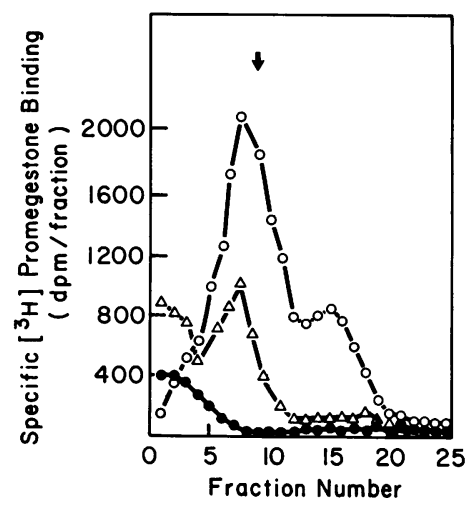

Figure 3. Density gradient analysis of $\left[{ }^{3} \mathrm{H}\right]-$ promegestone binding in cytosol of mouse breast. 12-wk-old virgin female mice were castrated and left untreated (five animals), treated with $0.7-\mathrm{cm}$ estradiol implants (five animals), or treated with 0.7 cm estradiol implants plus $0.1 \mathrm{~cm}$ dihydrotestosterone implants (five animals). The mice were killed $5 \mathrm{~d}$ later, and the inguinal breasts were removed, weighed, and homogenized with an equal volume of TEGSH buffer containing $10 \mathrm{mM}$ sodium molybdate. The cytosol fraction was prepared, incubated with $5 \mathrm{nM}$ [17 $\alpha$-methyl${ }^{3} \mathrm{H}$ ]promegestone and analyzed by density gradient analysis as described in the text. The protein concentration in the three cytosol preparations were $8.2,7.6$, and $8.8 \mathrm{mg} / \mathrm{ml}$, respectively. For this plot the nonspecific binding observed in the presence of $500 \mathrm{nM}$ nonradioactive promegestone was subtracted so that specific binding only is seen. The arrow indicates the location of the ${ }^{14} \mathrm{C}$-albumin marker. $-0-$, estradiol treated; $-\Delta-$, treated with estradiol plus dihydrotestosterone; $-\bullet-$, untreated.

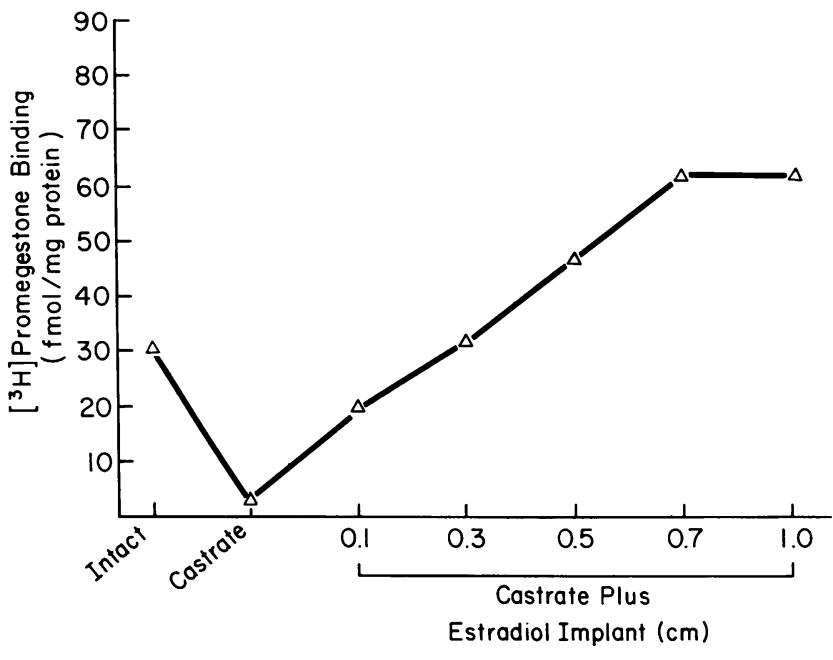

Figure 4. Effect of estradiol implants on $\left[{ }^{3} \mathrm{H}\right]$ promegestone binding by mouse breast cytosol. Castrated 12-wk-old virgin female mice were left untreated or were given estradiol implants as indicated. The mice were killed $5 \mathrm{~d}$ later, and cytosol was prepared from the inguinal breasts, incubated with $5 \mathrm{nM}\left[17 \alpha\right.$-methyl- $\left.{ }^{3} \mathrm{H}\right]$ promegestone, and analyzed by density gradient as before. The points represent mean values of two experiments, each of which constituted a pool of five animals for each determination.

cm dihydrotestosterone capsules blocked the enhancement by about half, and the increase was completely prevented at a dosage of $0.5 \mathrm{~cm}$ dihydrotestosterone.

To investigate the mechanism by which dihydrotestosterone blocks this action of estradiol, we first asked whether the effect of dihydrotestosterone, like the inhibition of embryonic differ-

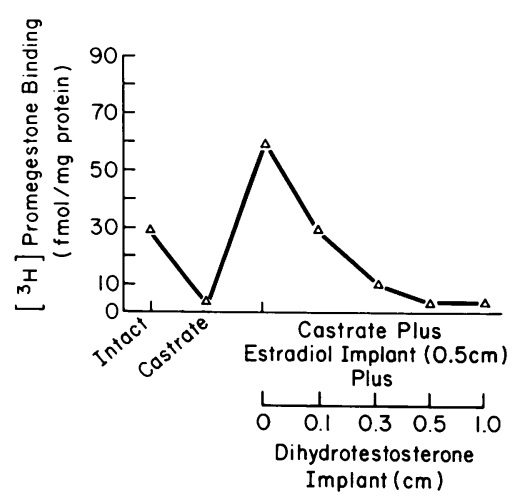

Figure 5. Effect of dihydrotestosterone on estradiol-stimulated enhancement of promegestone binding in mouse mammary gland. Castrated 12-wk-old virgin female mice were left untreated or were given $0.7 \mathrm{~cm}$ estradiol implants with or without dihydrotestosterone implants as indicated. The mice were killed $5 \mathrm{~d}$ later, and cytosol was prepared from the inguinal breasts, incubated with $5 \mathrm{nM}$ [17 $\alpha$ methyl- ${ }^{3} \mathrm{H}$ ]promegestone, and analyzed by density gradient as before. Each point represents a mean value of two experiments, each of which constituted a pool of five animals for each assay. 
entiation of the breast in the mouse (11) and the antiestrogenic action in uterus (12), acts via the androgen receptor. To this end, we turned to the $t \mathrm{fm}$ mouse which lacks a functional androgen receptor (23) (experiment 1, Table I). As in female mice, castration causes disappearance of the progesterone receptor from the breast of the tfm mouse, and estradiol implants cause a doubling of the level of the receptor as compared with the intact control. Dihydrotestosterone inhibits the estradiol-mediated increase in the progesterone receptor similarly in the $t f m$ and control animals. The fact that maximal level of receptor in this experiment is less than that of the $\mathrm{CBA} / \mathrm{J}$ mice is probably a consequence of the genetic background (C57BL/J mice) upon which the $t a$ and $t f m$ mutations are carried rather than a consequence of the mutations themselves. Therefore, we repeated the experiment in $F_{1}$ crosses between CBA/J males and inbred females carrying the $t a$ and tfm mutations (experiment 2, Table I). Once again, the antiestrogenic action of dihydrotestosterone was similar in control females and in the $t \mathrm{fm}$ males. We concluded that the antiestrogenic action of dihydrotestosterone in these mice is not mediated by the androgen receptor.

We then examined the possibility that dihydrotestosterone acts as an antiestrogen at the level of the estrogen receptor. The effects of androgens on the binding of $\left[{ }^{3} \mathrm{H}\right]$ estradiol to the estradiol receptor are illustrated in Fig. 6 . The data have been plotted as a ratio of $\left[{ }^{3} \mathrm{H}\right]$ estradiol binding in the absence and in the presence of varying amounts of testosterone, $3 \beta$-androstanediol, dihydrotestosterone, and $5 \beta$-dihydrotestosterone. $\left[{ }^{3} \mathrm{H}\right]$ Estradiol binding was weakly competed by dihydrotestosterone and $3 \beta$-androstanediol, very weakly by testosterone,

Table I. Effect of Dihydrotestosterone on Estrogen-stimulated Enhancement of Promegestone Binding in the Breast of the Tfm/Y Mouse

\begin{tabular}{|c|c|c|c|c|c|}
\hline \multirow[b]{3}{*}{ Group } & \multirow[b]{3}{*}{$\begin{array}{l}\text { Hormone } \\
\text { treatment }\end{array}$} & \multicolumn{4}{|c|}{ Promegestone binding ( $\mathrm{fmol} / \mathrm{mg}$ protein) } \\
\hline & & \multicolumn{2}{|c|}{ Experiment 1} & \multicolumn{2}{|c|}{ Experiment 2} \\
\hline & & $t a+/ t a+$ & $+t f m / Y$ & $\begin{array}{l}+t f m /++ \\
t a+/++\end{array}$ & $+t f m / Y$ \\
\hline Intact & None & 5.7 & 9.3 & 32 & 19 \\
\hline Castrate & None & 0 & 0 & 0 & 0 \\
\hline Castrate & Estradiol & 16 & 18 & 157 & 89 \\
\hline Castrate & $\begin{array}{l}\text { Estradiol } \\
\text { plus dihydro- } \\
\text { testosterone }\end{array}$ & 0 & 2.9 & 34 & 14 \\
\hline
\end{tabular}

Each experiment represents an average of two studies in which four 13-wk-old animals in each group were either left intact, castrated, or castrated and treated for $5 \mathrm{~d}$ with $0.7-\mathrm{cm}$ estradiol implants or with implants containing $0.7-\mathrm{cm}$ estradiol plus $0.5 \mathrm{~cm}$ dihydrotestosterone. In experiment 1 , the animals carrying the $t a$ and $t \mathrm{fm}$ genes were inbred upon a C57/BL6 background. In experiment 2 , the animals were $F_{1}$ crosses between $\mathrm{CBA} / \mathrm{J}$ males and inbred $t a^{+} /+t f m$ females. Specific $\left[{ }^{3} \mathrm{H}\right]$ promegestone binding was assessed and estimated as described in the text. Protein concentration in the cytosols varied from 6.0 to 8.6 $\mathrm{mg} / \mathrm{ml}$.

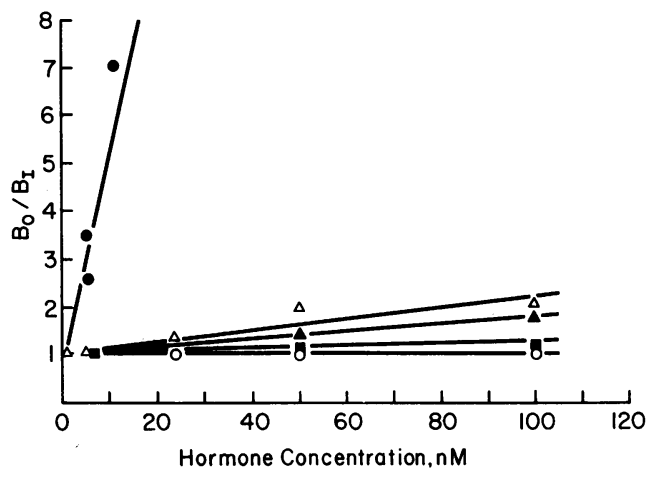

Figure 6. Effect of androgens on $\left[{ }^{3} \mathrm{H}\right]$ estradiol binding by mouse breast cytosol. Breasts from 20 castrated, 12-wk-old female virgin mice were pooled, and the cytosol was prepared as before. Aliquots were incubated with $5 \mathrm{nM}\left[2,4,6,7-{ }^{3} \mathrm{H}\right]$ estradiol alone or with various nonradioactive steroids as indicated and analyzed by the density gradient technique. The data have been plotted as a ratio of the amount of $8 \mathrm{~S}$ binding in the absence of added steroid $\left(\mathrm{B}_{\mathrm{o}}\right)$ to the amount of binding in the presence of nonradioactive steroid $\left(B_{1}\right) . \bullet$, estradiol; $\Delta$, dihydrotestosterone; $n$, testosterone; $\circ, 5 \beta$-dihydrotestosterone; $\Delta, 3 \beta$-androstanediol.

and not at all by $5 \beta$-dihydrotestosterone, even at concentrations up to 70-fold greater than that of estradiol. Other steroids that were found ineffective in preventing estradiol binding to the estradiol receptor were androstenedione and $5 \alpha$-androstane$3 \alpha, 17 \beta$-diol ( $3 \alpha$-androstanediol) (results not shown). By this estimate estradiol binds to the estrogen receptor with an affinity that is approximately fifty times greater than that of dihydrotestosterone. These four 19-carbon steroids show a similar hierarchy in inhibiting estradiol-mediated induction of the progesterone receptor; namely, dihydrotestosterone is more effective than $3 \beta$-androstanediol and testosterone, and $5 \beta$ dihydrotestosterone is ineffective in this regard (Table II).

Since some estrogen antagonists that bind to the estrogen receptor have the capacity to anchor the cytoplasmic receptor in the nucleus; we then investigated the effect of 2 wk of dihydrotestosterone treatment on the intracellular distribution of the estradiol receptor in mouse breast (Fig. 7). In the preparation from the animals that had received dihydrotestosterone, more estradiol receptor was recovered in the nuclear fraction than in the cytosol, but there was no effect on the total amount of estradiol receptor recovered (cytoplasmic plus nuclear).

\section{Discussion}

In hopes that an animal model might provide insight into the pathogenesis of gynecomastia in men, we have investigated the interaction of androgen and estrogen in the breast of the mouse. The mouse was utilized because of the availability of the $t \mathrm{fm}$ mouse which lacks a functional androgen receptor 
Table II. Effect of Androgens on Estradiol-mediated Enhancement of Promegestone Binding in Breast Tissue from Castrated Female Mice

\begin{tabular}{ll}
\hline Hormone treatment & $\begin{array}{l}\text { Promegestone } \\
\text { binding }\end{array}$ \\
\hline & fmol/mg protein
\end{tabular}

Estradiol $(0.7 \mathrm{~cm})$ alone

93

Estradiol $(0.7 \mathrm{~cm})$ plus dihydrotestosterone $(0.5 \mathrm{~cm})$

22

Estradiol $(0.7 \mathrm{~cm})$ plus $5 \beta$-dihydrotestosterone $(0.5 \mathrm{~cm})$

Estradiol $(0.7 \mathrm{~cm})$ plus testosterone $(0.5 \mathrm{~cm})$

105

Estradiol $(0.7 \mathrm{~cm})$ plus $3 \beta$-androstanediol $(0.5 \mathrm{~cm})$

84

58

12-wk-old female mice were castrated, and groups of five either received no therapy or were implanted with estradiol or estradiol plus androgen as indicated. After $5 \mathrm{~d}$, specific $\left[{ }^{3} \mathrm{H}\right]$ promegestone binding was assessed and estimated as described in the text. Protein concentrations in the cytosol varied from 4.2 to $8.8 \mathrm{mg} / \mathrm{ml}$. These represent the average of three experiments.

(23), recognizing that rodent breast differs from that of man in one important regard. This difference is that androgens act in utero to suppress development of the male mouse breast (20), whereas in the human there is no evidence for sexual dimorphism of breast development until the time of puberty

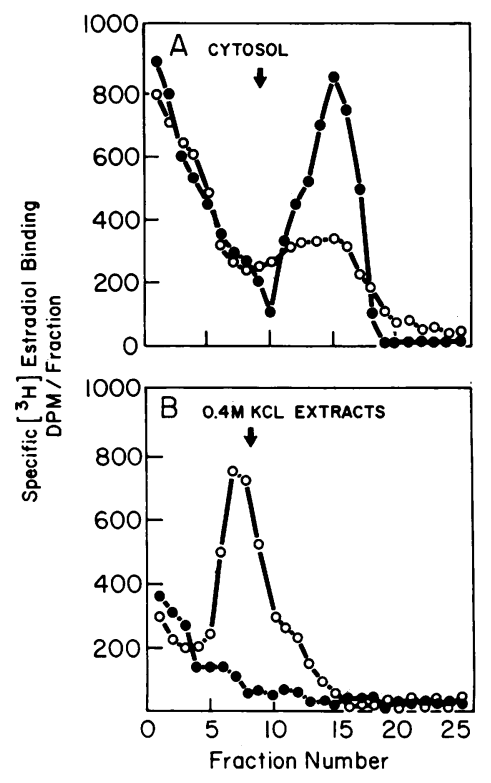

Figure 7. Sucrose density gradient analysis of estradiol binding in breasts of castrated mice and from mice treated with dihydrotestosterone. 12-wk-old castrated virgin female mice were studied after no treatment or 2 wk after placement of a $1-\mathrm{cm}$ dihydrotestosterone implant. Breasts from five animals were pooled, homogenized, and centrifuged as before. After aspiration of the cytosol fraction, $1 \mathrm{ml}$ of $0.4 \mathrm{M}$ $\mathrm{KCl}$ in TEGSH buffer containing $10 \mathrm{mM}$ sodium molybdate was added, and the pellet was homogenized in a Dounce homogenizer and recentrifuged at $100,000 \mathrm{~g}$ for $1 \mathrm{~h}$. The cytosol and the $0.4 \mathrm{M} \mathrm{KCl}$ extract were incubated with $5 \mathrm{nM}[2,4,6,7-$ ${ }^{3} \mathrm{H}$ ]estradiol for $4 \mathrm{~h}$ at $0^{\circ} \mathrm{C}$ and analyzed by sucrose density gradient as before. The arrow indicates the site of the ${ }^{14} \mathrm{C}$-albumin marker. $-\bullet-$, castrated controls; - - , dihydrotestosterone-treated.
(24). Therefore, we utilized the breast of the virgin female mouse for these studies.

Estrogen treatment to such mice stimulates breast growth and as in other species increases the amount of progesterone receptor in the breast. Both effects of estradiol can be inhibited by dihydrotestosterone. We concluded that this might be an adequate model system for investigating the mechanism of the antiestrogenic action of androgen, and we designed experiments to assess two mechanisms that have been proposed for this action, namely that androgen acts at the genomic level via its own receptor to block estrogen action or that androgen acts as a pharmacological antagonist and/or weak estrogen agonist by competing with estradiol for the estrogen receptor. The findings in these experiments favor the latter possibility. Indeed, the fact that dihydrotestosterone was equally effective in blocking estrogen effects in $t \mathrm{fm} / \mathrm{Y}$ and control mice suggests that this action of androgen is not mediated by the androgen receptor. If this interpretation is correct, then this effect of androgen is different than the antiestrogenic effect of the hormone in the embryonic mouse breast (11) and in the uterus (12).

Dihydrotestosterone binds weakly to the estrogen receptor in mouse breast and like some other antiestrogens appears to anchor the estrogen-receptor in the nucleus of the cell. These effects have only been studied with pharmacological amounts of hormone, but the fact that the relative binding affinities of dihydrotestosterone, $3 \beta$-androstanediol, testosterone, and $5 \beta$ dihydrotestosterone correlate with their capacities to inhibit induction of the progesterone receptor is in keeping with the finding in MCF7 tumor cells (10) that androgens bind to the estrogen receptor. Unlike the situation in MCF7 cells, however, we were unable to demonstrate any estrogen-like effects of dihydrotestosterone on the mouse breast.

Demonstration that this model system provides insight into the estrogen-androgen interaction in the human breast will require additional studies of several types. First, the concentration of hormones at which androgen antagonizes estrogen action in the human is within the physiological range and it may be necessary to perform long-term studies in mice using smaller implants to determine whether this system is in fact analogous to the human breast. In addition, levels of androgens and estrogens in the breast and in plasma will have to be carefully monitored. Second, these findings leave unexplained the failure of the breast to feminize in men with $5 \alpha$ reductase deficiency (25); namely, we found that testosterone is a weaker antagonist of estrogen in mouse breast than is dihydrotestosterone and it would logically follow that when dihydrotestosterone formation is impaired in the face of normal estrogen formation and action, the breasts might enlarge. However, there appears to be a species variability in that the human estrogen receptor binds testosterone and dihydrotestosterone with similar affinities (10), and consequently, it is possible that in the human male testosterone and dihydrotestosterone are equally effective antagonists of estrogen. Again, this phenomenon will have to be investigated in receptors 
derived from human breast. Third, it has been generally assumed, certainly by us, that feminization of the breasts in human subjects with defective androgen receptor (testicular feminization [complete and incomplete] and the Reifenstein syndrome) is in large part due to androgen resistance (25). However, estrogen production is also increased in these states, and it may be that estrogen itself is the primary determinant of breast enlargement in these disorders (1).

If androgen prevents the development of gynecomastia in normal men by acting as a direct antiestrogen at the level of the estrogen receptor, this is the first androgen action recognized that is not mediated by the androgen receptor.

\section{Acknowledgments}

This work was supported by grant AG00306 from the U.S. Public Health Service. Dr. Casey was the recipient of a fellowship from the Medical Research Council of Canada.

\section{References}

1. MacDonald, P. C., J. D. Madden, P. F. Brenner, J. D. Wilson, and P. K. Siiteri. 1979. Origin of estrogen in normal men and in women with testicular feminization. J. Clin. Endocrinol. Metab. 49:905916.

2. Wilson, J. D., J. Aiman, and P. C. MacDonald. 1980. The pathogenesis of gynecomastia. Adv. Int. Med. 25:1-32.

3. Edman, C. D., A. J. Winters, J. C. Porter, J. D. Wilson, and P. C. MacDonald. 1977. Embryonic testicular regression. A clinical spectrum of XY agonadal individuals. Obstet. Gynecol. 49:209-217.

4. Aiman, J., P. F. Brenner, and P. C. MacDonald. 1980. Androgen and estrogen production in elderly men with gynecomastia and testicular atrophy after mumps orchitis. J. Clin. Endocrinol. Metab. 50:380-386.

5. Gabrilove, J. L., G. L. Nicolis, H. A. Mitty, and A. R. Sohval. 1975. Feminizing interstitial cell tumor of the testis: personal observations and a review of the literature. Cancer. 35:1184-1202.

6. Gabrilove, J. L., E. K. Freiberg, E. Leiter, and G. L. Nicolis. 1980. Feminizing and non-feminizing Sertoli cell tumors. J. Urol. 124:757-767.

7. Gordon, G. G., J. Olivo, F. Rafii, and A. L. Southren. 1975. Conversion of androgens to estrogens in cirrhosis of the liver. J. Clin. Endocrinol. Metab. 40:1018-1026.

8. Lewin, M. L. Gynecomastia. 1941. The hypertrophy of the male breast. J. Clin. Endocrinol. Metab. 1:511-514.

9. Gabrilove, J. L. 1974. Some recent advances in virilizing and feminizing syndromes and hirsutism. Mt. Sinai J. Med. 41:636-654.

10. Zava, D. T., and W. L. McGuire. 1978. Androgen action through estrogen receptor in a human breast cancer cell line. Endocrinology. 103:624-630.

11. Kratochwil, K., and P. Schwartz. 1976. Tissue interaction in androgen response of embryonic mammary rudiment of mouse: identification of target tissue for testosterone. Proc. Natl. Acad. Sci. USA. 73:4041-4044.

12. Rochefort, H., and M. Garcia. 1984. The estrogenic and antiestrogenic activities of androgens in female target tissues. Pharmacol. Ther. 23:193-216.

13. Montelaro, R. C., and R. R. Rueckert. 1975. Radiolabeling of proteins and viruses in vitro by acetylation with radioactive acetic anhydride. J. Biol. Chem. 250:1413-1421.

14. Schneider, W. C. 1955. Determination of nucleic acids in tissues by pentose analysis. Methods Enzymol. 3:680-684.

15. Burton, K. 1956. A study of the conditions and mechanism of the diphenylamine reaction for the colorimetric estimation of deoxyribonucleic acid. Biochem. J. 62:315-322.

16. Foote, R. H., and W. A. Greene. 1978. Release rate of testosterone and estrogens from polydimethylsiloxane implants for extended periods in vivo compared with loss in vitro. Int. J. Fertil. 23:128-132.

17. Lowry, O. H., N. J. Rosebrough, R. J. Randall, and A. L. Farr. 1951. Protein measurement with the folin phenol reagent. J. Biol. Chem. 193:265-275.

18. Martin, R. G., and B. N. Ames. 1961. A method for determining the sedimentation behavior of enzymes: application to protein mixtures. J. Biol. Chem. 236:1372-1379.

19. Bartlet, J. C., and D. M. Smith. 1960. The determination of the areas of resolved and partially resolved chromatography peaks. Can. J. Chem. 38:2057-2065.

20. Kratochwil, K. 1977. Development and loss of androgen responsiveness in the embryonic rudiment of the mouse mammary gland. Dev. Biol. 61:358-365.

21. Haslam, S. Z., and G. Shyamala. 1981. Relative distribution of estrogen and progesterone receptors among the epithelial, adipose, and connective tissue components of the normal mammary gland. Endocrinology. 108:825-830.

22. Horwitz, K. B., and W. L. McGuire. 1977. Progesterone and progesterone receptors in experimental breast cancer. Cancer Res. 37:1733-1738.

23. Goldstein, J. L., and J. D. Wilson. 1972. Studies on the pathogenesis of the pseudohermaphroditism in the mouse with testicular feminization. J. Clin. Invest. 51:1647-1658.

24. Pfaltz, C. R. 1949. Das embryonale und postnatale Verholten der Mannlichen brustdruse beim Menschen. Acta Anat. 8:293-328.

25. Wilson, J. D., J. E. Griffin, M. Leshin, and P. C. MacDonald. 1983. The androgen resistance syndromes: $5 \alpha$-reductase deficiency, testicular feminization, and related disorders. In The Metabolic Basis of Inherited Disease. J. B. Stanbury, J. B. Wyngaarden, D. S. Fredrickson, J. L. Goldstein, and M. S. Brown, editors. McGraw-Hill, New York. 1001-1026. 